\title{
PEMBUATAN BAHAN DASAR BIOETHANOL SEBAGAI UPAYA PEMANFAATAN LIMBAH KULIT BUAH NANGKA PADA CV. KAJEYE FOOD MALANG \\ Harimbi Setyawati ${ }^{1}$, Erni Junita Sinaga ${ }^{2}$, Jimmy $^{3}$ \\ Institut Teknologi Nasional Malang \\ e-mail: arimbisetya@yahoo.co.id
}

\begin{abstract}
Abstrak - CV. Kajeye Food merupakan sebuah perusahaan yang bergerak dibidang pengolahan makanan yakni keripik buah dan sayur, dengan meningkatnya produksi nangka dari tahun ke tahun akan berbanding lurus dengan produktivitas limbah nangka. Saat ini pembuangan limbah jerami nangka menjadi permaslahan bagi CV. Kajeye Food, untuk itu diperlukan penyuluhan dan pelatihan pembuatan gula reduksi yang merupakan bahan dasar dari bioethaniol. Jerami nangka merupakan bagian buah nangka yang tidak mengalami menyerbukan berbentuk serat-serat berwarna kuning. Jerami nangka memiliki komposisi yang terdiri dari 13,45\% pati, 65,05\% air. Bahan ini dapat dikonversi untuk bioetanol melalui hidrolisis dan proses fermentasi. Salah satu upaya terbaik untuk pengolahan limbah kulit nangka dengan cara menjadikan Potensi kandungan pati jerami nangka dapat dimanfaatkan sebagai alternatif bahan bakar yaitu, bioetanol. Pengolahan buah nangka seringkali menimbulkan limbah, dari berat keseluruhan buah nangka sebanyak $65-80 \%$ dapat menjadi limbah. Jerami nangka menempati porsi cukup besar yaitu $40-50 \%$ dari total limbah yang dihasilkan. Jerami nangka mengandung karbohidrat berupa gula, kandungan gizi seperti dalam buah nangka dan selulosa. Hasil dari pengabdian kepada masyarakat dapat menghasilkan gula reduksi dimana pihak mitra diberi waktu untuk melakukan percobaan dan dari 10 orang yang melakukan ujicoba hampir 100\% mampu membuat gula reduksi yang nantinya dapat dimanfaatkan untuk proses pembuatan bahan bioethanol.
\end{abstract}

Kata Kunci: Limbah Buah Nangka, Bahan Dasar, Gula Reduksi

\section{PENDAHULUAN}

CV. Kajeye Food merupakan sebuah perusahaan yang bergerak dibidang pengolahan makanan yakni keripik buah dan sayur di kota Malang yang didirikan oleh bapak Ir. Kristiawan sejak tahun 2002. CV. Kajeye Food bergerak di bidangan pengolahan buah, khususnya di bidang keripik dan manisan buah dengan merk SoKressh Bermacam - macam hasil keripik buah dan manisannya, diantaranya adalah keripik nangka, mangga, salak, nanas, apel, jambu merah, pepaya, bengkuang, lengkeng, durian, jamur, wortel, sayuran, manisan nangka, nanas, jambu, apel, dan lainnya. CV. Kajeye Food telah memiliki sertifikasi Dep Kes P-IRT, Halal MUI, ISO 9001 : 2008, HACCP (Hazard Analysis Critical Control Points), sehingga hygienitas produk dan keamanan pangan terjamin karena telah ditangani sesuai standar nasional dan internasional.

CV. Kajeye Food yang beralamatkan di Jalan Polowijen II Nomor 359 Malang, sebagai salah satu pusat belanja oleh-oleh khas Malang yang menjadikan para pelanggan suka adalah dibolehkanya para pengunjung melihat proses produksi, sehingga jaminan kualitas produk dapat dilihat secara langsung .

Semakin meningkatnya industri kripik buah di CV. Kajeye Food dan meningkatnya produksi nangka dari tahun ke tahun akan berbanding lurus dengan produktivitas limbah nangka. Salah satu upaya terbaik untuk pengolahan limbah jerami 
nangka dengan cara menjadikannya sebagai gula reduksi untuk pembuatan bahan dasar bioethanol.

Dengan diberikannya penyuluhan tentang manfaat jerami nangka sebagai bahan dasar pembuatan bioethanol diharapkan dapat memberikan wawasan pengetahuan bagi mitra dan masyarakat sekitanya.

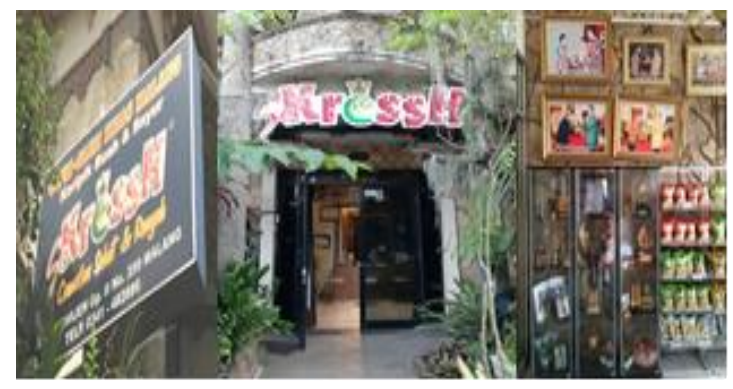

Gambar.1. CV Kajeye Food dengan merk SoKressh

Jerami nangka yang memiliki unsur karbohidrat yang tinggi dalam komposisinya juga sebagian besar didominasi oleh air. Komposisi jerami nangka per 100 gram mengandung $65,05 \%$ air, karbohidrat $13,45 \%$, abu 3,5\%, protein $1,5 \%$, lemak $1,93 \%$, serat kasar $3,55 \%$ serta komposisi lain nya berupa calsium potasium dan lainlain (Sharma dkk, 2015).

Ekstraksi pati merupakan proses untuk mendapatkan pati dari suatu tanaman dengan cara memisahkan pati dari komponen lainnya yang terdapat pada tanaman tersebut (Sakinah, 2018).

Ekstraksi pati dilakukan dengan bantuan pelarut. Pelarut yang dapat digunakan diantaranya air dan etanol. Penggunaan air sebagai pelarut disebabkan ketersediaan air yang melimpah dan murah. Jika ditinjau berdasarkan kepolarannya, merupakan pelarut yang tergolong semipolar yang baik dalam mengekstraksi komponen dalam bahan pangan (Sari, 2013).

Limbah jerami nangka berisi kandungan pati dan serat yang kasar yang mana dapat digunakan sebagai bahan utama sumber glukosa. Glukosa yang terbentuk dapat diolah kembali menjadi produk baru yang lebih bermanfaat, contohnya seperti alkohol dan lain sebagainya (Indra, 2010).

Rumusan masalah dalam pengabdian masyarakat ini adalah memberikan penyuluhan kepada pemilik maupun karyawan pada untuk dapat memanfaatkan limbah dari buah-buahan terutama limbah jerami nangka menjadi gula reduksi sebagai bahan dasar Bioethanol.

\section{METODE}

Menyadari adanya potensi dan permasalahan dari industri kripik buah di CV. Kajeye Food di kota Malang tentang limbah padat dari buah nangka yang belum berlimpah, maka dipandang perlu untuk mengadakan kegiatan yang menunjang program ini, dengan memberikan penyuluhan cara pembuatan gula reduksi sebagai bahana dasar bioethanol dari jerami buah nangka. Metode yang digunakan dapat dilihat pada flowchart sebagai berikut : 


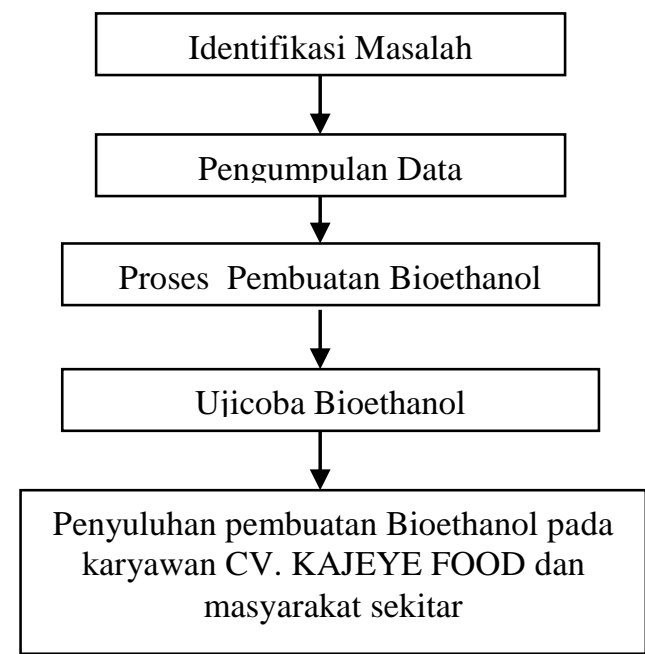

Gambar 2. Metode Pelaksanaan Kegiatan Pengabdian Kepada Masyarakat

\section{HASIL KARYA UTAMA DAN PEMBAHASAN}

Pada kegiatan pengabdian ini akan dilakukan penyuluhan dan pelatihan pembuatan memanfaatkan limbah dari jerami buah nangka menjadi gula reduksi yang nantinya dapat dijadikan sebagai bahan dasar Bioethanol. Adapun tahapan proses penyuluhan pembuatan gula reduksi dilaksanakan beberapa tahap sebgai berikut :

\section{Tahap persiapan}

Tim pengabdian masyarakat mengidentifikasi kegiatan yang ada di industri keripik buah CV. Kajeye Food

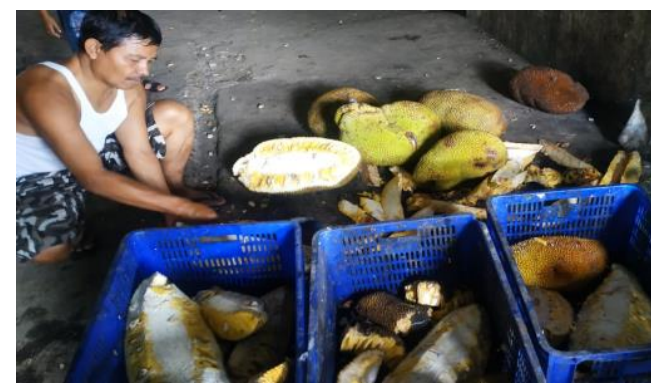

Gambar 3. proses pemotongan buah Nangka
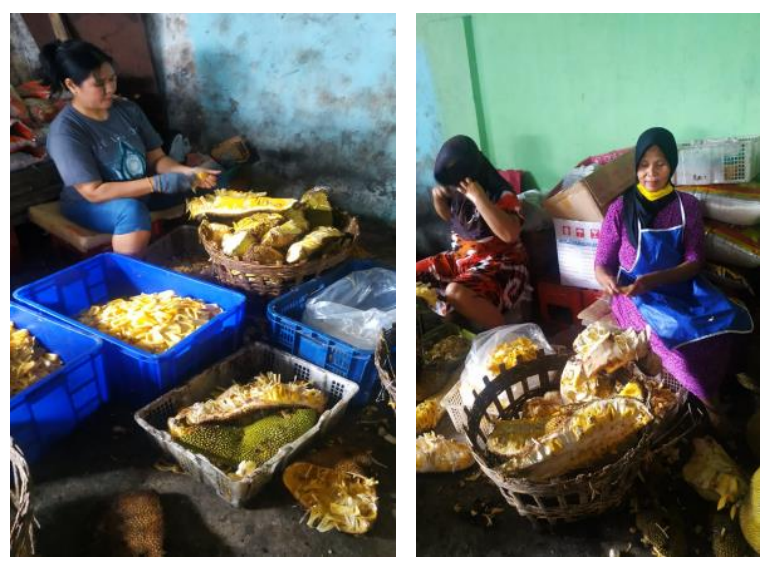

Gambar 4. proses pemisahan buah Nangka dan jerami nangka 


\section{Tahap Pelaksanaan}

Tim pengabdian kepada masyarakat memberikan arahan proses pembuatan gula reduksi sebagai bahan dasar bioethanol

Proses Pembuatan Bioethanol

\section{a. Pengeringan}

-Limbah kulit nangka dicuci dengan air untuk menghilangkan kotoran yang ada, lalu direndam dengan larutan air garam 5\% selama 15 menit.

-Bahan dikeringkan dengan Dehydrator pada suhu 65 oC sehingga jerami nangka kering dan kadar air $<14,5 \%$.

-Bahan yang sudah kering dihancurkan dengan menggunakan blender.

-Serbuk hasil blender kemudian diayak menggunakan ayakan 40 mesh sehingga menghasilkan ukuran yang diinginkan.
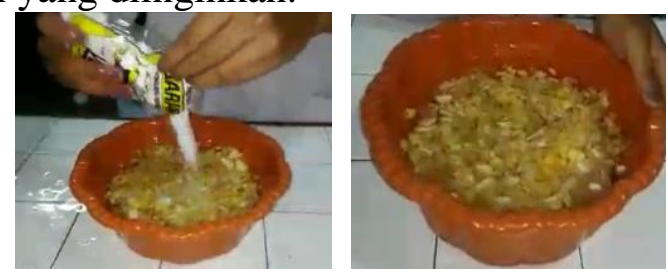

Gambar 5. Jerami nangka yang direndam dengan air garam

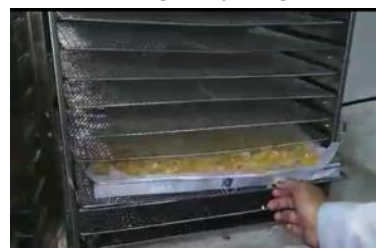

(a)

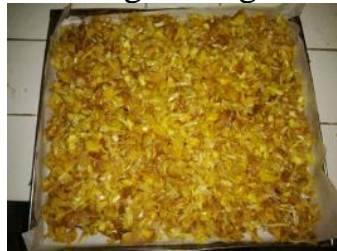

(b)

Gambar 6. Jerami nangka dalam loyang yang telah dilapisi kertas (a) dan proses pengeringan jerami nangka $(b)$

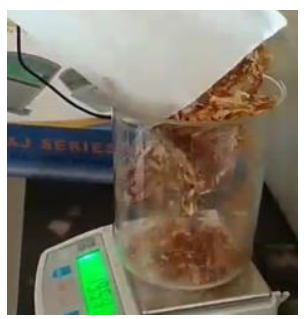

(a)

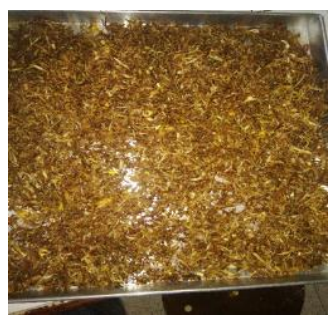

(b)

Gambar 7. Jerami nangka yang telah dikeringkan (a) dan jerami kering yang ditimbang (b)
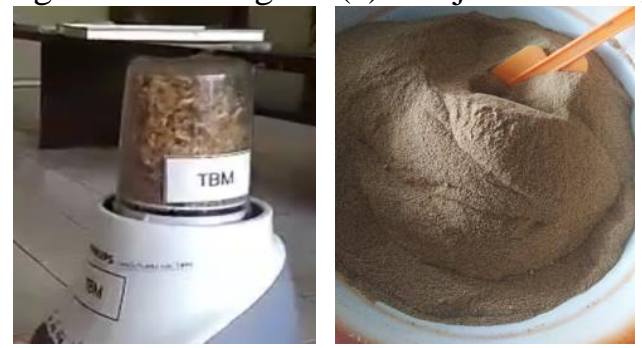

Gambar 8. Proses blender jerami nangka agar menjadi serbuk (kiri) dan setelah diayak (kanan) 
b.Ekstraksi

- Melarutkan serbuk jerami nangka menggunakan pelarut dengan rasio 1:10 (b/b)

- Campuran direndam dan disertai pengadukan 300 rpm selama 5, 10, 15, 20, 25 menit

- Campuran disaring dan diperas menghasilkan filtrat pati dan ampas

- Ampas diekstraksi kembali sampai 3 kali

- Filtrat pati diendapkan selama 2 jam

- Pati hasil endapan dikeringkan dengan pengeringan Dehydrator suhu $40^{\circ} \mathrm{C}$ selama \pm 10 jam

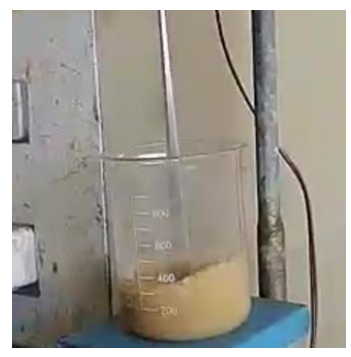

Gambar 9. Proses pengadukan larutan serbuk jerami nangka

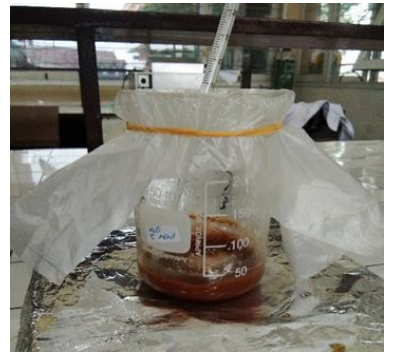

(a)

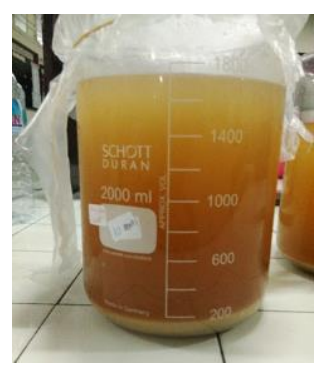

(b)

Gambar 10.Proses pengendapan filtrat (a) dan Proses hidrolisis serbuk Nangka (b)

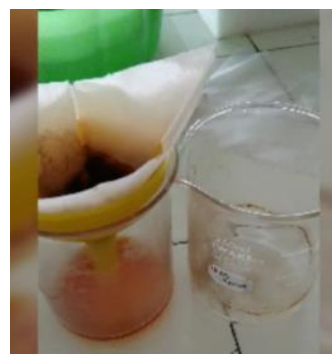

(a)

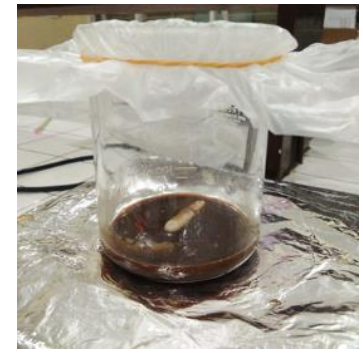

(b)

Gambar 11. larutan hasil hidrolisa (a) dan larutan yang di saring (b)

c. Hidrolisis

- Melarutkan pati hasil ekstraksi menggunakan pelarut dengan rasio 1:10 (b/v) kemudian dimasukkan bahan ke dalam Beakerglass,

- Atur suhu $90{ }^{\circ} \mathrm{C}$ dan kecepatan pengadukan sakla 6 dilakukan selama 1,5 jam.

- Sampel hasil hidrolisis dilakukan analisis kadar gula reduksi. 


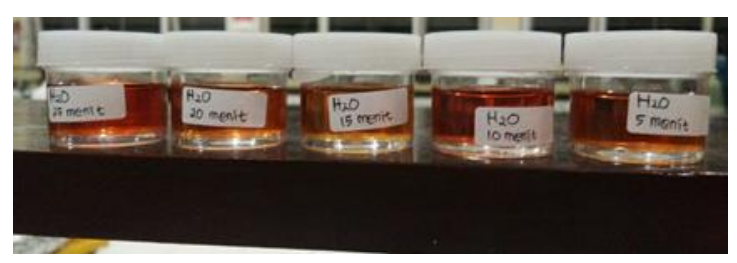

(a)

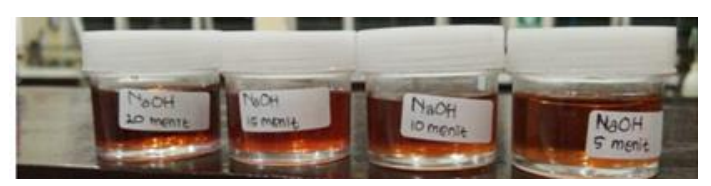

(b)

Gambar 12. Larutan gula reduksi dengan pelarut $\mathrm{H} 2 \mathrm{O}$ (a) dan $\mathrm{NaOH}$ (b)

\section{Tahap Evaluasi}

Setelah tim pengabdian kepada masyarakat memberikan penyuluhan dan pelatihan tentang pembuatan gula reduksi, pihak mitra diberi waktu untuk melakukan percobaan dan dari 10 orang yang melakukan ujicoba hampir $100 \%$ mampu membuat gula reduksi yang nantinya akan dimanfaatkan untuk proses pembuatan bahan bioethanol.

\section{KESIMPULAN}

Pada kegiatan pengabdian masyarakat di CV.Kajeye Food tingkat ketercapaian target $100 \%$ hal ini didukung karena peran serta aktif dari mitra dimana pemilik dan karyawan yang bekerja di industri keripik tersebut sangat antusias untuk mempelajari dan nantinya semakin ahli untuk mengolah limbah padat jerami nangka yang saat ini menjadi permasalahan utama pembuangan limbah. Dengan adanya penyuluhan dari tim Pengabdian masyarakat limbah jerami nangka dapat diolah menjadi produk yang bisa bermanfaat dengan demikian hal tersebut dapat memberikan penyelesaian permasalahan tentang limbah jerami nangka yang selama ini belum dimanfaatkan dan diharapkan dengan adanya kegiatan penyuluhan pembuatan gula reduksi ini tidak hanya memberikan wawasan bagi mitra pemilik dan pekerja di industri keripik buah CV. Kajeye Food akan tetapi dapat pula disebarluaskan ke masyarakat sekitarnya.

\section{UCAPAN TERIMA KASIH}

Pada kesempatan ini Tim Pengabdian Kepada Masyarakat menyampaikn ucapan terimakasih kepada mitra khususnya CV. Kajeye Food serta pihak Lembaga Penelitian dan Pengabdian Kepada Masyarakat ITN Malang yang telah membantu dalam penulisan jurnal baik berupa materiil maupun moril.

\section{DAFTAR PUSTAKA}

Adikhairani, 2012. Pemanfaatan Limbah Nangka ( Biji: Artocarpus Hete Rophyllus, Lmk Dan Dami Nangka) Untuk Pembuatan Berbagai Jenis Pangan Dalam Rangka Penganekaragaman Penyediaan Pangan. Medan: Universitas Negeri Medan.

Karim, A. dan Sutjahjo D.H. 2013. Uji Kinerja Mesin 4 Langkah Berbahan Bakar Bioethanol Dari Limbah Kulit Jerami Nangka Sebagai Campuran Premium. Surabaya: Universitas Negeri Surabaya.

Mardiyah, S. dan Widyaningrum, T. 2015. Perbandingan Kadar Etanol Hasil Fermentasi Substrat Dami Nangka (Artocarpus Heteropyllus Lamk.) Dengan 
Menggunakan Kultur Murni Trichoderma viride dan Saccharomyces cerevisiae. Yogyakarta: Universitas Ahmad Dahlan.

Meyrinta, K.A. dkk. 2018. Pembuatan Bioetanol Dari Jerami Nangka Dengan Metode Fermentasi Menggunakan Saccharomyces Cereviseae. Samarinda: Universitas Mulawarman.

Sakinah, A.R. dan Kurniawansyah, I.S. 2018. Isolasi, Karakterisasi Sifat Fisikokimia, Dan Aplikasi Pati Jagung Dalam Bidang Farmasetik. Bandung: Universitas Padjajaran.

Sari, F.K. dkk. 2013. Ekstraksi Pati Resisten Dari Tiga Varietas Kentang Lokal Yang Berpotensi Sebagai Kandidat Prebiotik. Jember: Universitas Jember.

Sharma, Anubhuti. dkk. 2015. Preliminary Nutritional And Biological Potential of Artocarpus Heterophyllus L. Shell Powder. India: Department of Bioscience and Biotechnology, Banasthali University 